\title{
Introduction to "After the Storm: Postal Politics and Labor Relations Following the 1970 U.S. Postal Wildcat Strike, 1970-1981"
}

\author{
Victor G. Devinatz ${ }^{1}$
}

Published online: 15 December 2017

(C) Springer Science+Business Media, LLC, part of Springer Nature 2017

The 1970 United States postal wildcat strike, a landmark strike conducted by federal postal workers, resulted in the four major postal unions, the National Association of Letter Carriers (NALC), the American Postal Workers Union (APWU), the National Postal Mail Handlers Union, and the National Rural Letter Carriers Association obtaining collective bargaining rights which included the right to bargain over wages, benefits and working conditions. The eight-day strike, which is the largest wildcat strike to have occurred in the United States, started in New York City although within a fortnight, it had expanded to other cities. Due to the illegal nature of this strike against the federal government, President Nixon utilized the US military personnel and the National Guard in an attempt to continue mail delivery and to end the strike. In addition to achieving collective bargaining rights, the walkout resulted in no strikers being terminated and affected the passage of the Postal Reorganization Act of 1970 and led to the formation of the United States Postal Service.

In this excellent and insightful article, Dr. Philip F. Rubio, Associate Professor of History at North Carolina A\&T State University, discusses the complex nature of US postal labor relations in the decade after the 1970 wildcat strike. While the traditional view is that postal union leaders engaged in negotiation and lobbying throughout the 1970s while the rank and file postal employees quietly returned to work, Rubio demonstrates that the 1970 strike inaugurated a "democratic movement culture" among postal union members that included local wildcat strikes, strike threats, combative negotiations, the imposition of a trusteeship on the NALC's largest and most militant local union while union dissidents obtained control of the NALC and the APWU.

If any of the journal's readers are interested in responding to any essays published in the "Perspectives" Section or would like to write articles on any topics in the field of employee relations, please do not hesitate to contact me with your proposal. I welcome both practitionerbased and scholarly-based articles written from any one of a variety of theoretical perspectives. I hope that you enjoy this article and find it most illuminating.

Victor G. Devinatz

vgdevin@ilstu.edu

1 Department of Management \& Quantitative Methods, Illinois State University, Normal, IL 61790-5580, USA 